\title{
Microstructures Analyses of Malay Keris and Its Relation to Mechanical Properties
}

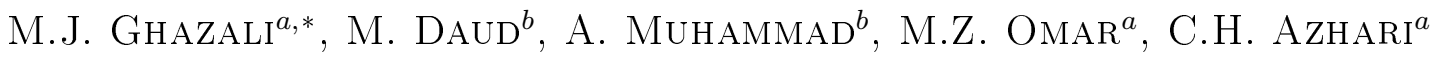 \\ ${ }^{a}$ Department of Mechanical \& Materials Engineering Faculty of Engineering \& Built \\ Environment University Kebangsaan Malaysia 43600 Bangi, Selangor, Malaysia \\ ${ }^{b}$ Malaysian Nuclear Agency Bangi, 43000 Kajang Malaysia
}

\begin{abstract}
The traditional steps in the fabrication of Malay Keris blades which are preserved in traditional knowledge are explained in consistency with the modern metallurgical engineering. These are forging, quenching, tempering and etching. The material selection process for specific parts of the blade is discussed and correlated to the particular fabrication method used to produce the final properties, which consist of the ductility, hardness and the watermark pattern on the blade. Morphologies of the microstructure are also in agreement with the observed properties in which the central strip of the blades possesses some ductility to facilitate forging whereas the harder edge area is made of steel with higher carbon content
\end{abstract}

DOI: $10.12693 /$ APhysPolA.127.1358

PACS: $81.40 .-\mathrm{z}$

\section{Introduction}

Keris, originally used as a fighting weapon has now become one of typical traditional crafts with artistic characteristics. This double-edged dagger with wavy or straight blade is unique because it is only found within the Malay Archipelago. However, in Malaysia, Keris making is considered as a dying art [1]. To date, many monographies and literature sources have been published [2-6] but most of them only focused on the historical background, design, pattern and the blade making simply ignoring the technology behind it, which is actually the real essence that is consistent with today's science. The history of several types of iron used in Keris [7] is still in infancy and normally described through the eyes of ancient blacksmiths. In ancient times, blacksmiths were considered among the elite occupations and assumed to be a principal contributors in creating early concepts [8] of understanding the behavior of metals, particularly iron. It is also clear that they had enough information from their forging work, the observation of color changes during spark test and heating as well as their estimation of hardness by scratch tests, in order to determine some key parts of the present-day iron-carbon phase diagram [8].

Keris can be divided into two parts: mata/bilah (blade) and hulu (hilt) (refer to Fig. 1). Its distinctive wavy edges known as $l u k$, are always odd in number, from three to thirteen waves. One of the most attractive characteristics of the blade is the watermark pattern called pamor as shown in Fig. 2, which represents the characteristic deformation pattern on the blade [6, 7]. In recent reviews [7, 9] ancient Keris blade consists of alternating metals that bonded at the interfaces. These materi-

*corresponding author; e-mail: mariyam@eng.ukm.my

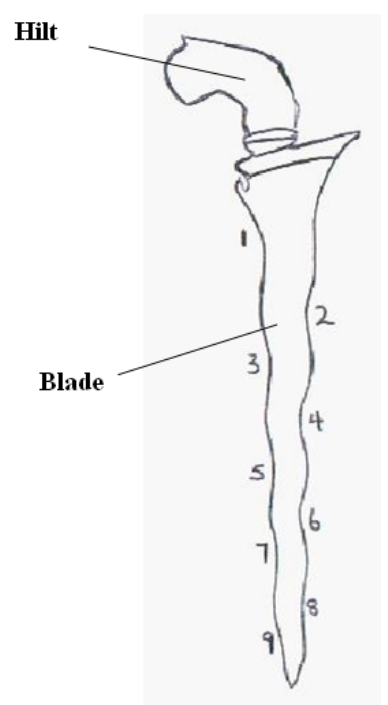

Fig. 1. Main component of a Keris. Numbers 1-9 indicate the total number of $l u k$.

als represent a unique laminated or composite structure that is far different from the monolith materials with diffusion interfaces or layered materials. As such, it is also known as the laminated metal composites (LMCs) that can significantly improve many properties of metal including fracture toughness, fatigue behavior, impact behavior, wear, corrosion and damping capacity, or provide enhanced formability or ductility, particularly for brittle materials [10]. In many cases, the laminate architecture and the processing history of LMCs are essential and can be engineered to produce a material with predicted properties. Thus, historical studies of ancient metallurgy are an important contribution to understand, not just for the benefit of the blade making, but also to the evolution of man and civilization. Due to an unsystematic documentation on Keris blade in the Malay world, an initiative 


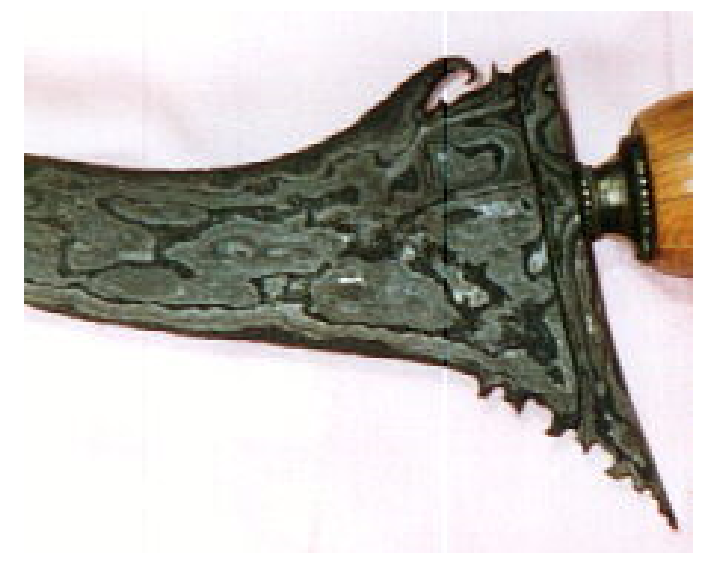

Fig. 2. Distinctive pamor on a Keris blade.

has been taken to revive this dying art. In this work, the microstructural examinations and the phase diagram modeling of two distinguished parts of the Keris blade; namely the central strip and the edge parts are studied. Correlation between the blacksmiths' experiences from interviews and existing iron-carbon phase diagram as well as the spark test are also discussed.

\section{Materials and method}

Discreet interviews with several Malay blacksmiths proved that there are many methods available to create a thorough understanding of iron and the Keris blade. In general, three principal guidelines were followed: a) observation of the colour of iron as it is sectioned and heated for forging and heat treatment, b) determining the strength of iron, that could be characterised by the ease of forging, with a function of temperature, c) determining the strength and hardness of iron at ambient temperature, by bending the iron, depending on the forging temperature and the cooling rate. An assumption of irons having two distinct structures; high and low carbon content was also applied to this guidelines. The following metals were commonly used in a Keris blade manufacturing; (a) iron mainly for the bulk of the blade, (b) steel for the sharp edges and (c) nickel steel for the patterns (pamor) on the blade surface. The selection was made based on the good mechanical properties like strength and ductility. In general, the iron bar was hot forged and folded into two equal pieces (U shape) before inserting a pamor sheet. The most striking feature of the Keris is the damascene pamor or most precisely 'alloy' that designates both the nickel steel used for Keris making and the type of damascene steel in the blade. The word pamor comes from the Javanese word which means mixture; describing the manufacturing procedure of the Keris $[11,12]$. This proves that a Keris is not made from a homogenous piece of metal. The iron/pamor combination was remelted, hot forged and folded again into 2 pieces, resulting in 4 layers of iron and 2 of pamors. The process was repeated and may reached up to 128 layers of pamor. In making the wavy luk effect, a lateral hot forging was utilised with help of a cylindrical tool. Most Kerises have fewer than 13 luks and there will always be an odd number [12]. Some smiths may reheat the blade to red hot color and tempered in a container with coconut oil, for extra toughening. Finally, the blade is treated (etched) with a mix of lime juice to bring out the pamor contrast, whereby the nickel alloy content will suffer less chemical attack than that of iron and the steel cutting edge [12]. Normally, the base iron may turn black in the solution while the nickel remains unaffected; emerging as silvery lines against a black background.

In the old days, most of forging works were carried out in a dark setting [10] in order to identify the changes of temperature with ease. First, the blacksmith noted that the wrought iron became weaker (easier to forge) as the temperature increased. That is the reason why traditionally, hot forging is most recommended for the deformation of metal that features a high formability ratio. Figure 3 illustrates the temperatures of forged blade by appearance, which can be assessed by their colour. The blacksmith noted that the properties of wrought iron changed when the iron combined with carbon. New temperatures were observed for every glitter effect, indicating that the colour description was a strong function of the amount of charcoal (carbon) [10]. It is understood that most iron and steel become softer and forgeable when heated to red and higher temperature. Normally, a good rule of thumb for most steel and iron is to work when it is heated to yellow colour.

Chemical composition of the as received blade elements.

TABLE I

\begin{tabular}{c|c|c|c|c|c|c|c|c|c|c|c|c}
\hline \hline \multicolumn{10}{c}{ Average element content [wt.\%] } \\
\hline \multirow{3}{*}{ Edge } & $\mathrm{Cn}$ & $\mathrm{Si}$ & $\mathrm{Mn}$ & $\mathrm{P}$ & $\mathrm{S}$ & $\mathrm{Ni}$ & $\mathrm{Cr}$ & $\mathrm{Cu}$ & $\mathrm{Mo}$ & $\mathrm{V}$ & $\mathrm{Co}$ & $\mathrm{Mg}$ \\
\cline { 2 - 12 } central & 0.80 & 0.565 & 1.27 & 0.036 & 0.057 & 0.430 & 0.171 & 0.125 & 0.108 & 0.10 & 0.29 & 0.41 \\
& 0.317 & 0.165 & 0.407 & 0.024 & 0.017 & 0.142 & 0.084 & 0.405 & 0.021 & 0.008 & 0.015 & -
\end{tabular}

\subsection{Raw materials}

Composition of as-received raw iron that normally used for the central and edge strips was analysed and recorded, as shown in Table I.

Clearly, the edge strip comprised of higher carbon content than those of the central parts, supporting the state- ments of the bushy spark pattern observed by the local smiths whilst examining the samples. Other elements like $\mathrm{Si}, \mathrm{Ni}$ and $\mathrm{Mn}$ also played important roles, particularly in giving higher strength, hardness and ductility to the blade, respectively [10]. Thus, this proves that embedded deep into the material of the blade are different types of steel and iron, each contributing to the blade's effective- 


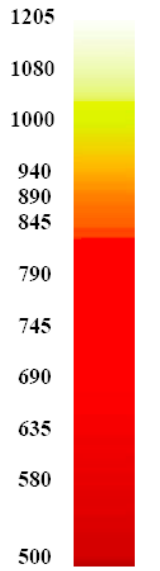

Fig. 3. Colour vs temperature $\left({ }^{\circ} \mathrm{C}\right)$ of forged blade.

ness and its unique design. From the composition, several conclusions can be drawn particularly on the fact that the steel is basically iron, in which when adding a little bit of carbon, greater strength than the iron would have by itself can be achieved. Figure 4 shows the morphologies of both irons with different carbon content. Microstructural observation confirmed that the structure of edge part was predominantly hypereutectoid steel (with approximately more than 0.77 wt.\% C) due to the presence of pearlite with small grains of iron carbide $\left(\mathrm{Fe}_{3} \mathrm{C}\right)$ also known as cementite, scattered throughout. Thus, with higher carbon content at the edge part of the Keris, it would suit best for the purpose of stabbing rather than the low carbon of core parts that normally used to absorb impact without breaking [13]. The ancient blacksmiths could physically see iron, but they had no idea how essential the carbon was. Indeed they understood that charcoal (in which is the origin of carbon) was greatly needed for the process, but carbon was not discovered as an element until just a few hundred years later [14].

\section{Results and discussion 3.1 Hardness profile}

The forged Keris blade was also tested for its hardness using a Rockwell Hardness tester (150 kgf). Figure 5 shows an illustration of the blade. The indentation was carried out on both sides; the forged surface as well as the backside that was in contact with the anvil. Table II displays the complete hardness profile of the Keris blade. The forged surface area was found to be in the range of 5-16 HRC, in a descending order from base to tip, and the other side of the blade, which was in contact with the anvil, showed similar manner, ranging from 7-16 HRC. These inconsistencies are attributed to the variance in the forging action and the used temperature during the heat treatment. The heterogeneity of the microstructures can be best viewed in Figure 6 and 7. Clearly, the cross sectional observations are in line with the hardness data whereby smaller grain size were predominantly contributing to greater hardness.

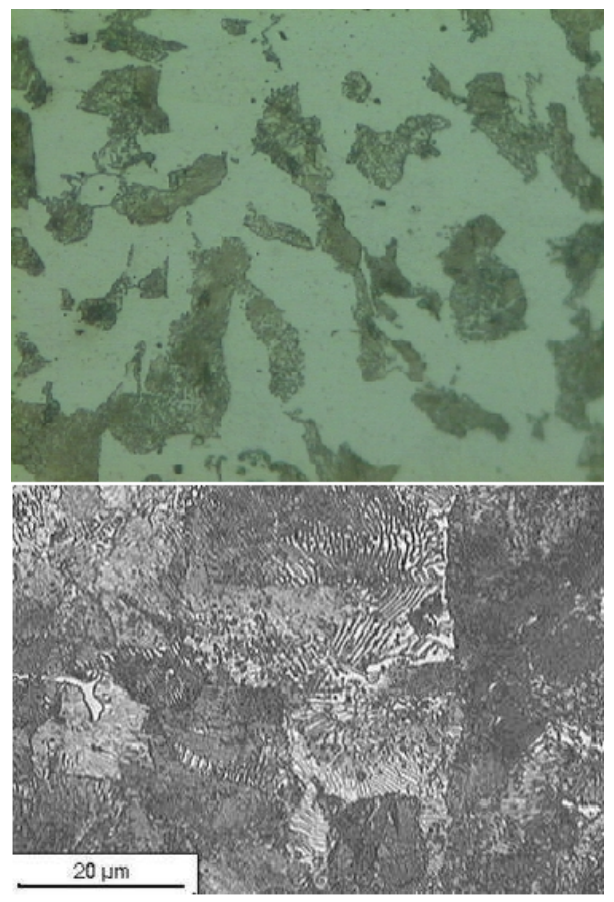

Fig. 4. As received irons indicating the (a) low carbon and (b) high carbon steel. The bright contrasts represent ferrite whereas the darker regions are predominantly pearlite (ferrite \& $\mathrm{Fe}_{3} \mathrm{C}$ mixtures).

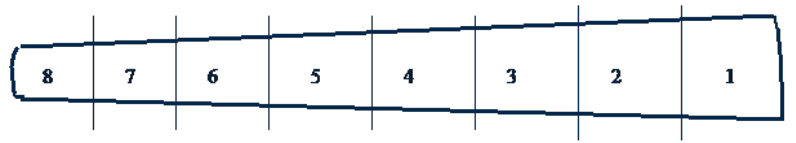

Fig. 5. Location of indentations.

\subsection{Scientific viewpoint vs ancient blacksmiths}

In the very hot centre of the furnace, the iron and carbon combined. This process happened at the atomic level. By nature, iron atoms bonded to one another in a specific geometric arrangement. At high temperature, more spaces between the iron atoms are available. But when this high temperature cooled quickly (by quenching), it contracted, and the carbon atoms became trapped in between the iron atoms. When the spaces are too small for the carbon atoms to fit into the structure, very hard and strong steel is formed. Thus, manipulating this heating and cooling process, as well as controlling the ingredients in the steel, allows metallurgists or ancient craftsmen to change the properties of the metal.

Heating softened the steel for hammering so that the pieces can be formed into one. The hammering (in forging action) also drove out most of the remaining impu-

Hardness profile of Keris blade (150 kgf).

TABLE II

\begin{tabular}{c|c|c|c|c|c|c|c|c}
\hline \hline Location & 1 & 2 & 3 & 4 & 5 & 6 & 7 & 8 \\
\hline Forged surface & 11 & 13.3 & 15.6 & 15.9 & 9.5 & 7.8 & 9.5 & 5.3 \\
Backside surface & 12.5 & 15.7 & 14.5 & 11.6 & 9.0 & 7.5 & 12.0 & 10.0
\end{tabular}



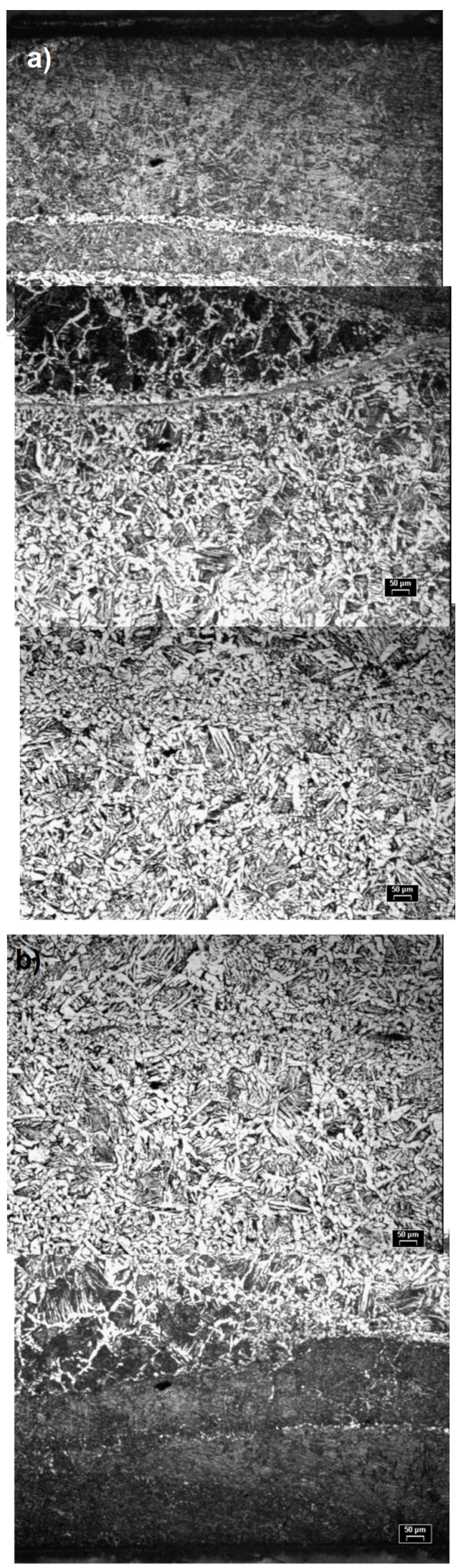

Fig. 6. Cross sectional view of the base location on (a) backside and (b) forged surfaces.
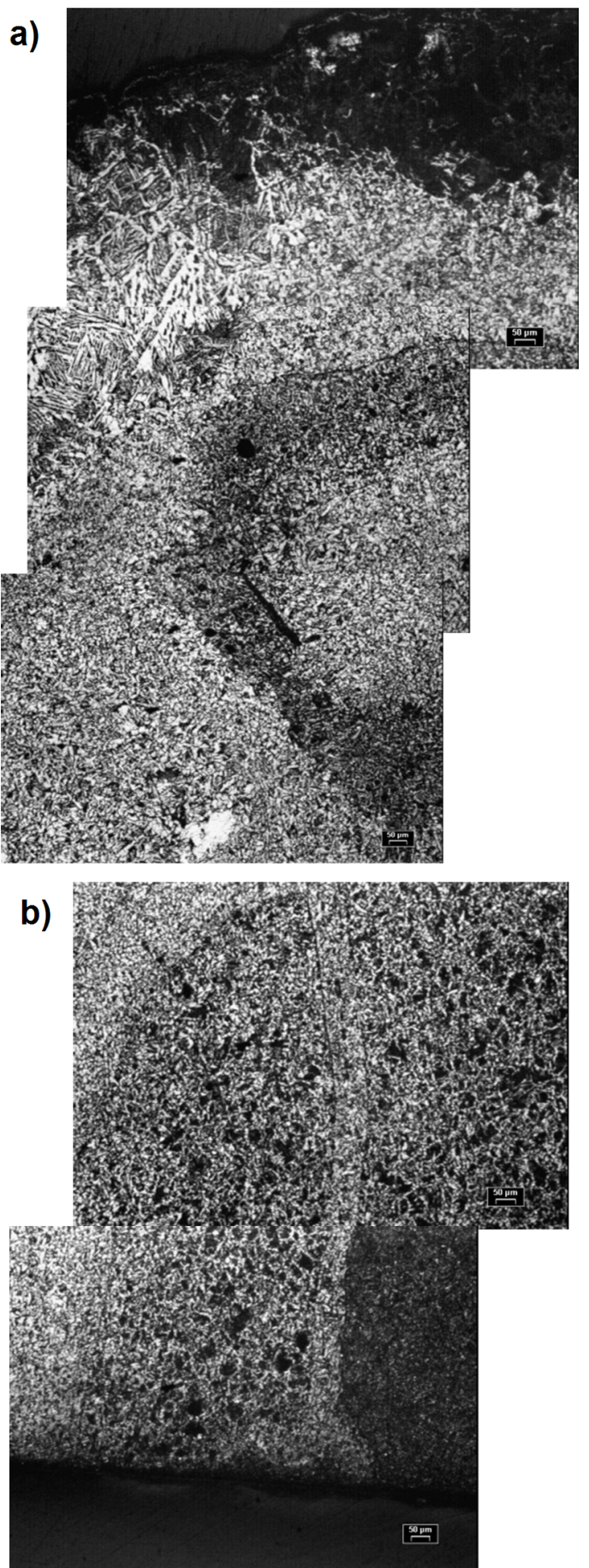

Fig. 7. Cross sectional view of the tip location on (a) forged and (b) backside surfaces.

rities, called slag. The material was actually getting harder as hammered. As already mentioned, the steel was pounded flat and then folded time and time again to thoroughly mix the iron and carbon. Normally, the bearer needs a Keris that is both hard and durable. In reality, hard metals, with more carbon, which normally held an edge, were brittle and break easily. Tough metals however, will bend, but could not hold an edge. Dur- 
ing forging, the tougher low-carbon steel was heated to a glowing red and inserted into the core (of the edge). This relatively simple procedure is the culmination of a great deal of work and key to the ultimate success of the Keris.

In addition, most smiths claimed that selected irons that used for edge areas melted easily and faster than that of the central areas; which certainly due to the high content of carbon, lowering the melting point and its temperature resistance. This statement can be supported with the aid of JMatPro (Java-based Materials Properties Software) modeling analysis as shown in Fig. 8a and $8 \mathrm{~b}$. Carbon content was believed to influence the yield strength of steel because carbon atoms fit into the interstitial crystal lattice sites of the arrangement of the iron atoms. The interstitial carbon reduces the mobility of dislocations, which in turn has a hardening effect on the iron. To get dislocations to move, a high enough stress level must be applied in order for the dislocations to "break away". This is because the interstitial carbon atoms caused some of the iron lattice cells to distort.
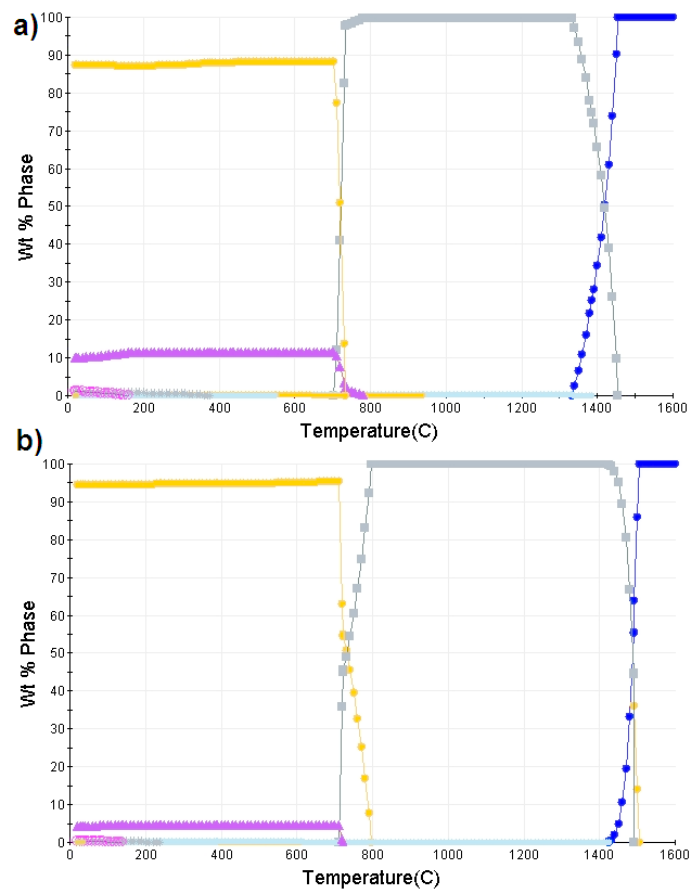

Fig. 8. Phase diagrams generated by JMatPro indicating the melting point of (a) edge and (b) central areas of the materials used for Keris blade.

\section{Conclusions}

This study not only highlighted the thought of metals as being solid; shiny and conduct electricity and heat really well, perhaps more importantly, they have the ability to bend, to deform and also to have their mechanical properties controlled. Thus, by adjusting their chemistry and controlling their heat treatment, one may have a lot of control over their properties. In conclusion, the Keris is a relatively straightforward (despite the luk) laminated blade, using the various qualities of the steel and iron incorporated therein. It is sharp and yet durable that reflects the pride and skill of its makers. In short, the technology of this dying art; Keris blade is really consistent with the modern science and technology.

\section{References}

[1] E.L. Wan, Keris - Is it merely a sword?, http://www . thingsasian.com/stories, 2011.

[2] H. Arumbinang, Panunggalan - Pakem Padhuwungan, Yogya: Lembaga Javanologi 1985.

[3] F. Edward, The Kris- Mystic Weapon of the Malay World, Singapore Oxford University Press 1988.

[4] G. Hamzuri, Keris Jakarta: Penerbit Djambatan, 1984.

[5] M. Kamil, Seni dalam Senjata Melayu, Variasari, Kuala Lumpur, Variapop Group, 26, 1989.

[6] A.G. Latip, Pandai Besi dan Kesenian Persenjataan Melayu. Dewan Budaya, Kuala Lumpur, Dewan Bahasa dan Pustaka, 30-31, 1997.

[7] J. Wadsworth, D.R. Lesuer, Materials Characterizations, 45, 289 (2000).

[8] O.D. Sherby, J. Wadsworth, J. of Mat. Proc. Technol. 117, 347 (2001).

[9] S. Yub, Keris Melayu, Dewan Masyarakat, Jilid IV, Bil. 1, Kuala Lumpur, Dewan Bahasa dan Pustaka, 32, 1966.

[10] D.R. Lesuer, C.K. Syn, O.D. Sherby, J. Wadsworth, J.J. Lewandowski, W.H. Hunt Jr., International Materials Reviews 41, 169 (1996).

[11] B. Harsrinuksmo, ed. Ensiklopedi Keris, Jakarta: Gramedia Pustaka Utama 2004.

[12] P. de Vries, Traditional weapons of from Indonesia, http://www.kris-keris.com.

[13] T.V. Rajan, C. P. Sharma, A. Sharma, Revised Edition, Heat Treatment: Principles and Techniques, Prentice Hall of India, New Delhi 1994.

[14] D. Hamilton, Secrets of the Samurai swords, http: //www.pbs.org/wgbh/nova/transcripts/ 3412_samurai .html. 